\title{
Chemia Jędrzeja Śniadeckiego
}

\author{
ABSTRACT
}

\section{The chemistry of Jędrzej Śniadecki}

In Poland, Jędrzej Śniadecki was a continuator and one of the promoters of the French school of chemistry, initiated by the works of Antoine Lavoisier. Śniadecki came into contact with the foundations of this school, which included a new definition of the chemical elements, the principle of mass conservation and the oxygen theory of combustion, while still studying at the university in Kraków. His later studies at European universities and his knowledge of the most recent literature ultimately channelled his views on chemistry. This was reflected in Śniadecki's academic publications, in particular in his textbook: Poczatki chemii: stosownie do teraźniejszego tey umiejętności stanu dla pożytku uczniów i stuchaczów ułożony y za wzór lekcyi akademickich stużyć majace (The Beginnings of Chemistry: Composed in Accordance with the Current State of This Skill for the Benefit of Students and Auditors to Be Used as a Model for Academic Classes) Vilnius, 1800. It was the first original chemistry textbook in the Polish language. The author used his own chemical terminology, modelled after the new French terminology. The Polish systemic chemical terminology, which conveyed information about the type and composition of a given substance, had been introduced by Śniadecki three years earlier, during his lectures at Vilnius University. The names proposed by Śniadecki caught on and were used in Poland for several decades.

Jędrzej Śniadecki's original contribution to global science was his theory that explained the phenomenon of life and the interdependencies between matter in the animate and inanimate world. This theory, published in the years 1804-1811, in Warsaw in three parts, was translated into German and French. The Polish edition was entitled Jędrzeja Śniadeckiego medycyny doktora Teoria jestestw organicznych (Theory of Organic Beings by Jędrzej Sniadecki, Medical Doctor). The first part was of great significance for the development of 
organic chemistry. When this work is compared with later publications by Justus Liebig, it can be shown that Śniadecki's views had an impact on the writings of this German scholar.

Keywords: Jędrzej Śniadecki, chemistry textbook, Antoine Lavoisier, Antoine François Fourcroy, Justus Liebig, acid, combustion, chemical elements, radial elements, caloric, Vilnius, Vilnius University, chemical terminology, affinity, vestium, ruthenium

Słowa kluczowe: Jędrzej Śniadecki, podręcznik chemii, Antoine Lavoisier, Antoine François Fourcroy, Justus Liebig, kwasy, spalanie, pierwiastki, pierwiastki promieniste, cieplik, Wilno, Uniwersytet Wileński, nomenklatura chemiczna, powinowactwo, west (vestium), ruten

\section{O literaturze przedmiotu}

W bogatym piśmiennictwie naukowym poświęconym biografii oraz rozmaitym aspektom wielokierunkowej działalności Jędrzeja Śniadeckiego tematyka chemiczna aczkolwiek reprezentowana dość licznie - zajmuje miejsce stosunkowo skromne. Łatwo można się o tym przekonać, biorąc do rąk chociażby Stanisława Konopki Spis rozpraw $i$ artykułów o Jędrzeju Śniadeckim, ogłoszonych w latach od 1840 do $1968^{1}$. Pomocna pod tym względem jest także bibliografia ${ }^{2}$ wydana rok później przez Miejską i Powiatową Bibliotekę Publiczną w Żninie. Od wydania obydwu opracowań upłynęło półwiecze, które poprawiło nieco te proporcje, przynosząc dalsze prace, ukazujące Śniadeckiego jako chemika. O ile autorami wczesnych publikacji na ten temat byli w przeważającej mierze lekarze, o tyle opracowania nowsze są głównie dziełem historyków chemii. Różnicę dostrzega się natychmiast, albowiem lekarzy (a później także filozofów) interesowała przede wszystkim Teoria jestestw organicznych ${ }^{3}$ Śniadeckiego; chemików natomiast trzy wydania jego Początków chemii wraz z polskim nazewnictwem chemicznym oraz problematycznym odkryciem westu.

Wśród najważniejszych pozycji w literaturze dotyczącej chemicznego wątku badawczej i dydaktycznej działalności Śniadeckiego poczesne miejsce należy się bez wątpienia monografii Ignacego Z. Siemiona Wilno chemiczne do połowy XIX stulecia ${ }^{4}$. Jest to książka ukazująca chemiczne dokonania Śniadeckiego w szerokim historycznym kontekście, a przy tym w sposób wyczerpujący, z wielkim znawstwem przedmiotu i bardzo interesująco. Autor oparł swoje opracowanie głównie na źródłach drukowanych. Poddał analizie większość oryginalnych prac naukowych, pochodzących z pierwszej połowy

${ }^{1}$ S. Konopka, Spis rozpraw i artykutów o Jędrzeju Śniadeckim ogłoszonych w latach od 1840 do 1968 wtacznie, „Archiwum Historii Medycyny” 1969, t. 32, z. 1, s. 75-83.

2 E. Żurawska, J. Konieczyńska, Jędrzej Śniadecki 1768-1838. Bibliografia w wyborze, Żnin 1970.

${ }^{3}$ Np.: Z. Kramsztyk, Jędrzej Śniadecki, „,Teoryja (!) jestestw organicznych” w obec (!) dzisiejszych pojęć o życiu. Z portretem Śniadeckiego, Warszawa 1874; S. Łagowski, Jędrzej Śniadecki i jego „, Teoria jestestw organicznych” w setna rocznice pierwszego jej wydania. Szkic źródtowy i krytyczny, Lwów 1904, s. 185-265; A. Bednarczyk, Jędrzeja Śniadeckiego „,Teoria jestestw organicznych” (1804) w dwusetna rocznicę ogtoszenia dzieła, Warszawa 2004.

${ }^{4}$ I.Z. Siemion, Wilno chemiczne do połowy XIX stulecia, Komitet Historii Nauki i Techniki PAN. Rozprawy z Dziejów Nauki i Techniki, t. 20, Warszawa 2009. 
XIX wieku, mających mniej lub bardziej ścisły związek z chemią, pisanych przez wykładowców tego przedmiotu oraz przyrodników, aptekarzy i lekarzy. Nie ograniczył się do prac polskich autorów, lecz wileńską chemię potraktował znacznie szerzej. Sięgnął do niemieckich i francuskich czasopism naukowych, które czytywali wileńscy przyrodnicy, i wskazywał na wzajemne, ponadnarodowe powiązania uczonych.

O Śniadeckim jako chemiku pisali także inni chemicy, zajmujący się historią swojej dyscypliny. Ważną pozycję stanowi książka Jana Harabaszewskiego ${ }^{5}$, wybitnego metodyka nauczania chemii, poświęcona ocenie podręcznika Śniadeckiego. Wiktor Lampe ${ }^{6}$ zwrócił uwagę na nowatorstwo tego podręcznika, a Michalina Dąbkowska ${ }^{7}$ wskazała na jego rolę w kształtowaniu polskiego słownictwa chemicznego. Jednakże polskie słownictwo chemiczne, które wprowadził do literatury naukowej Śniadecki, przede wszystkim stało się przedmiotem badań Romana Mierzeckiego, autora obszernej monografii ${ }^{8}$ na ten temat. Teksty o Śniadeckim pisane przez chemików ukazały się również w poświęconej mu pracy zbiorowej ${ }^{9}$, wydanej w 1970 roku pod redakcją Ireny Stasiewicz. Były to w szczególności trzy artykuły, z których pierwszy, pióra Włodzimierza Hubickiego ${ }^{10}$, traktował o chemicznym wykształceniu Śniadeckiego; drugi - autorstwa Kazimierza Sarneckiego ${ }^{11}$ - ukazywał Śniadeckiego jako analityka; trzeci natomiast napisany przez Marię Sarnecką-Keller ${ }^{12}$ dotyczył poglądów tego wileńskiego chemika-lekarza na wzajemne relacje materii ożywionej i nieożywionej.

\section{Wznowienie wykładów chemii w Szkole Głównej Wielkiego Księstwa Litewskiego}

Po ostatnich prowadzonych przez Józefa Sartorisa zajęciach wiosną 1793 roku nastąpiła ponadczteroletnia przerwa w nauczaniu chemii w Wilnie. Powodem były dramatyczne okoliczności polityczne, które nie tylko zakłóciły normalne funkcjonowanie wileńskiej uczelni, ale wręcz zagroziły samemu jej bytowi (konfederacja targowicka, wojna z Rosją, powstanie kościuszkowskie i upadek państwa polskiego).

5 J. Harabaszewski, Jędrzej Śniadecki, nauczyciel chemii i pisarz rzeczy chemicznych, Lwów 1938.

6 W. Lampe, Początki chemii Jędrzeja Śniadeckiego, „Roczniki Chemii” 1950, t. 24, nr 1-6, s. $3-10$.

${ }^{7}$ M. Dąbkowska, Początki chemii Jędrzeja Śniadeckiego na tle powstawania polskiej nomenklatury chemicznej [w:] Księga pamiątkowa dziesięciolecia Uniwersytetu Marii Curie-Skłodowskiej w Lublinie 1944-1954, Lublin 1956, s. 177-195.

${ }^{8}$ R. Mierzecki, Rozwój polskiej terminologii chemicznej, Wrocław 1988.

${ }^{9}$ Rzecz o Jędrzeju Śniadeckim, red. I. Stasiewicz, Biblioteka Wiedzy Współczesnej - Omega, t. 165, Warszawa 1970.

${ }_{10}$ W. Hubicki, Studia chemiczne Jędrzeja Śniadeckiego [w:] Rzecz o Jędrzeju Śniadeckim..., s. 29-51.

${ }^{11}$ K. Sarnecki, Śniadecki - analityk, ale czy odkrywca rutenu? [w:] Rzecz o Jędrzeju Śniadeckim..., s. 52-61.

${ }_{12}$ M. Sarnecka-Keller, Zasadnicze tezy biologicznego światopoglądu Jędrzeja Śniadeckiego [w:] Rzecz o Jędrzeju Śniadeckim..., s. 62-79. 
Byt uniwersytetu w Wilnie pod rosyjskim zaborem udało się jeszcze tym razem uratować. Uczelnia ponownie rozpoczęła funkcjonowanie w 1797 roku. W tym samym roku stanowisko profesora chemii i farmacji objął w niej Śniadecki (1768-1838).

Jeśli zdobywającą sobie wówczas coraz większe uznanie w Europie „nową chemię” można by nazywać szkołą naukową stworzoną przez Antoine'a Lavoisiera (1743-1794), to Śniadecki należał do gorliwych kontynuatorów i propagatorów tej szkoły w Polsce. Z jej najwcześniejszymi założeniami, czyli nową definicją pierwiastków, prawem zachowania masy oraz tlenową teorią spalania, zetknął się już podczas studiów w Krakowie, słuchając wykładów Jana Jaśkiewicza (1749-1809) i Franciszka Scheidta (1759-1807). Późniejsze studia w najlepszych uczelniach europejskich oraz znajomość najnowszej literatury, w tym Philosophie Chimique Antoine'a François Fourcroy (1755-1809), ukierunkowały ostatecznie jego poglądy. Wiedział, że jednym z fundamentalnych elementów szkoły Lavoisiera było opracowanie i wprowadzenie do języka nauki systemowego nazewnictwa chemicznego. Miało być ono jednocześnie zapisem informacji o poszczególnych substancjach, ich rodzaju i budowie. Na przykład nazwa hydrogène od razu wskazywała, że określone przez nią ciało jest nieodzowne, aby mogła powstać woda, a oxyde de mercure - że tak nazwany związek chemiczny musi być połączeniem oxygène i mercure.

Francuskie słownictwo chemiczne szkoły Lavoisiera opracowali wspólnie Louis B. Guyton de Morveau (1737-1816), Antoine Laurent Lavoisier, Claude Louis Berthollet (1748-1822) oraz Fourcroy. Rzecz ${ }^{13}$ została opublikowana w Paryżu (pierwsze wydanie ukazało się w 1787 roku).

Od kiedy Śniadecki zaczął się zastanawiać, jak najtrafniej to nowe słownictwo francuskie przełożyć na język polski? Z pewnością czynił to odpowiednio wcześnie, zanim przystąpił do przygotowywania swoich wykładów. Używane w naszym kraju nazwy zwyczajowe, stanowiące dziedzictwo rzemiosł i alchemii, niejednoznaczne, kształtowane przez wieki w różnych regionach i profesjach, uważał bowiem za przeszkodę w rozwoju chemii jako nauki. Dał temu wyraz m.in. w Przedmowie do pierwszego wydania Początków chemii: ,dzisiejszą chemię uważać można na kształt matematyki, za ogólny klucz nie tylko do wszystkich kunsztów, ale i do wszystkich niemal umiejętności fizycznych służący"14. Aby istotnie chemia mogła taką funkcję pełnić, musiała dysponować słownictwem ujednoliconym i skorelowanym z teoriami, stanowiącymi jej podstawy.

Śniadecki nie był w swych poglądach odosobniony. Przed nim próbę adaptacji francuskiego słownictwa chemicznego i tworzenia w ten sposób polskiej nomenklatury naukowej podjął Ludwik Plater (1774-1826), wybitny leśnik i geograf, od 1805 roku wizytator Uniwersytetu Wileńskiego. Wiele zaproponowanych przez Platera nazw wykorzystał, a następnie ich liczbę bardzo wzbogacił Śniadecki, gdy jako pierwszy w Wilnie rozpoczął akademickie wykłady chemii w języku ojczystym.

${ }^{13}$ L.B. Guyton de Morveau, A.L. Lavoisier, C.L. Berthollet, A.F. Fourcroy, Méthode de nomenclature chimique on y a joint un nouveau Systême de Caractères Chimiques, adaptés à cette Nomenclature, par MM. Hassenfratz \& Adet, Paris 1787.

${ }^{14}$ J. Śniadecki, Poczatki chemii: stosownie do teraźniejszego tey umiejętności stanu dla pożytku uczniów i stuchaczów ułożony y za wzór lekcyi akademickich stużyć mające, t. 1, Wilno 1800 [Przedmowa s. nlb. 18]. 
Liczący ponad 30 stron słownik polskiej nomenklatury chemicznej wraz z odpowiadającym nazewnictwem łacińskim, ułożony przez Śniadeckiego, został opublikowany na końcu pierwszego wydania jego podręcznika. Zarówno podręcznik, jak i słownik miały wielki wpływ na kształcenie chemicznej młodzieży przez następne dziesiątki lat. Jako jeden z pierwszych słownictwo Śniadeckiego zastosował w literaturze naukowej Jan Gwalbert Bystrzycki (1772-1835), dokonując przekładu Filozofii chemicznej Antoine'a de Fourcroy ${ }^{15}$.

W czasach, gdy Śniadecki rozpoczynał pracę na Uniwersytecie Wileńskim, panowała dość powszechna fascynacja przyrodą, a zwłaszcza możliwościami praktycznego wykorzystania jej zasobów. Otwierało to szerokie pole dla chemii, która jak nigdy wcześniej budziła duże zainteresowanie wśród warstw uważających siebie za oświecone. Nie tracąc nic ze swej roli królowej kunsztów, stała się wówczas chemia także królową salonów. Wielu polskich arystokratów, nie wyłączając samego króla Stanisława Augusta Poniatowskiego, miało w swoich rezydencjach prywatne laboratoria chemiczne. Niektórzy, np. hrabia Aleksander Chodkiewicz (1776-1838), bardzo przyczynili się do rozwoju tej nauki. Inni ulegali raczej modzie niż pasji badawczej.

Nie było więc niczym dziwnym, że w tego rodzaju klimacie również publiczne wykłady chemii cieszyły się dużą popularnością. Zdarzało się, że i profesor Sartoris na swych uniwersyteckich prelekcjach w Wilnie miewał gości z zewnątrz. Bywały wśród tych gości nawet damy, chociaż wykładał po łacinie, zatem percepcja treści chemicznych w tym wypadku nie należała do łatwych. Gdy po nim Śniadecki zaczął wykładać w języku polskim, sala urządzonego przez Sartorisa zakładu chemii nie mogła pomieścić słuchaczy.

Zakład ten był nie tylko zbyt mały, ale także niedostatecznie wyposażony. Dlatego też Śniadecki od pierwszych chwil swojej akademickiej działalności rozpoczął starania o budowę nowego kolegium chemicznego, podobnego do tych, jakie widywał i w jakich się kształcił za granicą.

Niebawem jego w tym kierunku zabiegi przyniosły pożądane rezultaty. Budowa, mimo rozmaitych przeszkód, trwała zaledwie kilka lat. Kolegium, nad którego projektowaniem czuwał Śniadecki osobiście, stanęło przy placu św. Michała, na miejscu zajmowanym niegdyś przez zbór kalwiński.

Nowy gmach przedstawiał się okazale. Ponad połowę jego powierzchni zajmowało audytorium. Była to okrągła, dwupiętrowej wysokości, obszerna sala, której nadano charakter amfiteatru. Wysokie sklepienie, wsparte na czterech filarach, zapewniało doskonałą akustykę. W centralnym punkcie amfiteatru znajdował się stół laboratoryjny wraz z umieszczonym nad nim, wielkim digestorium, podtrzymywanym przez dwie kariatydy. Komin digestorium wyprowadzony był wysoko ponad dach, zwiększając bezpieczeństwo eksperymentowania, co było istotne zwłaszcza w wypadku doświadczeń z substancjami lotnymi i łatwo detonującymi ${ }^{16}$. Pomieszczenia przyległe do audytorium przeznaczone były na pracownie naukowo-dydaktyczne i gabinet profesorski.

15 A.F. de Fourcroy, Filozofia chemiczna czyli fundamentalne prawdy teraźniejszej chemii przez Antoine Francois de Fourcroya. Z francuskiego przetożona przez X. Jana Bystrzyckiego S.P. Towarzystwa Król. Warsz. Przyjaciół Nauk członka, profesora fizyki w szkołach warszawskich, Warszawa 1808, 312 ss. +8 nlb.

${ }^{16}$ B. Koskowski, [Słowo wstępne], Inwentarz Zakładu Chemii dawnego Uniwersytetu Wileńskiego zapoczątkowany przez Jędrzeja Śniadeckiego w roku 1797 i doprowadzony do końca przez Ignacego 
Ponieważ urządzone przez Śniadeckiego Kolegium Chemiczne miało nie tylko służyć kształceniu studentów, lecz także stanowić placówkę naukowo-badawczą, wyposażenie jego pracowni musiało być odpowiednio do tego dostosowane. Stale troszczył się o to Śniadecki, dokonując zakupów w kraju i za granicą oraz sprowadzając specjalistyczną literaturę.

Inaczej rzecz się miała, gdy chodziło o nauczanie na poziomie pozauniwersyteckim. Tu Śniadecki był raczej powściągliwy. W przedmowie do swego podręcznika dla szkół średnich napisał: „nie jest rzecz konieczna zakładać przy szkołach narodowych laboratoria chemiczne, gdyż do wyłożenia tych krótkich początków, dość będzie opatrzyć gabinety fizyczne narzędziami i materiałami takimi, które do ważniejszych i początkowych doświadczeń chemicznych nieuchronnie są potrzebne"17.

Inwentaryzacja Kolegium Chemicznego w Wilnie, obejmująca spis aparatury laboratoryjnej, odczynników chemicznych oraz innych najrozmaitszych preparatów, zakończona 40 lat później podczas ostatecznej likwidacji przez rosyjskiego zaborcę Uniwersytetu Wileńskiego, liczyła kilka tysięcy pozycji. W spisie nie brakowało najnowocześniejszych przyrządów. Wiele z nich miało dużą wartość materialną. Niektóre spośród odczynników i preparatów były nie tylko cenne naukowo, ale także kosztowne. Całe to mienie, z wyjątkiem rzeczy uznanych za nieprzydatne, zostało w 1842 roku zagrabione przez Rosjan i wywiezione - głównie do Kijowa.

\section{Pierwiastki promieniste i inne}

Zgodnie ze szkołą Lavoisiera nazywał Śniadecki pierwiastkami vel ciałami prostymi wszystkie takie substancje, których nie udało się rozłożyć na składniki prostsze. Tak sformułowana definicja miała charakter otwarty, ponieważ nie wykluczała, że w przyszłości niektóre z ciał uznanych za proste mogą zostać rozłożone.

Listę pierwiastków otwierały światło i cieplik. Wykazywały one podobieństwo na tyle duże, że wielu chemików - wśród nich Jöns Jacob Berzelius (1779-1848) - sądziło, że są to odmiany tego samego ciała. Byli też tacy, którzy twierdzili, że cieplik nie jest pierwiastkiem, lecz związkiem nieznanej substancji ze światłem ${ }^{18}$. Śniadecki był innego zdania. Uważał, że skoro ciepło jest przyczyną czucia, a światło - widzenia, to natura tych ciał musi być odmienna ${ }^{19}$. Rozróżniał przy tym ciepło od cieplika i przypuszczał, że ciepło jest tylko przejawem działania cieplika.

Fonberga. Materiat archiwalny zebrat i do druku opracowat Kazimierz Stawiński. W hołdzie Jędrzejowi Śniadeckiemu w stuletnia rocznice jego śmierci dokument ten wydaje Polskie Powszechne Towarzystwo Farmaceutyczne, Wilno 1938, s. 9-10.

17 A. Wrzosek, Jędrzej Śniadecki, Przedmowa do „,Krótkiego rysu chemii dla użytku szkół narodowych W. Księstwa Warszawskiego”. Z rękopisu wydat i wstępem poprzedził..., „Wszechświat” 1903, t. 22, nr 11 (1084), s. 161-164.

18 B. Koskowski, op. cit., s. 74.

19 J. Śniadecki, Objaśnienie niektórych punktów w nauce o ciepliku. Rzecz na posiedzeniu akademickim Uniwersytetu Wileńskiego dnia 15 marca 1815 roku czytana [w:] idem, Dzieła, t. 3, Warszawa 1840, s. 165. 
Według Śniadeckiego i wielu innych współczesnych mu badaczy pierwiastek cieplik odgrywał w chemii ważną rolę. Był najbardziej rozrzedzonym, sprężystym i najlżejszym ze znanych ciał. Miał zdolność przenikania do wnętrza wszystkich substancji i zmieniał ich stan skupienia. Najmniej cieplika zawierały ciała stałe, nieco więcej - ciecze, a najwięcej gazy, które traktowano jako roztwory różnych ciał w ciepliku.

Oryginalnym pomysłem Śniadeckiego było utworzenie oddzielnej grupy ciał prostych, na którą składały się oprócz światła i cieplika, także elektryczność i magnetyzm. Grupę tę nazwał pierwiastkami promienistymi i poświęcił im sporo miejsca w trzecim wydaniu swojego podręcznika ${ }^{20}$. Było to związane z nowymi odkryciami w chemii, które Śniadecki skrupulatnie śledził na bieżąco. Zwłaszcza wyizolowanie nowych pierwiastków dzięki użyciu stosu Volty mogło sugerować, że elektryczność jest ciałem aktywnym chemicznie. Magnetyzm natomiast został wśród pierwiastków promienistych wymieniony tylko dla porządku, ponieważ nie zaobserwowano, aby miał dla chemii istotne znaczenie.

Nazwę pierwiastki promieniste uzasadniał Śniadecki ich specyficznymi właściwościami: w stanie wolnym rozchodziły się nader szybko w postaci promieni, ich stan skupienia był daleko lotniejszy i rzadszy od gazów oraz mogły łatwo przenikać do innych ciał.

Każdy, kto przeczytał Początki chemii... (którekolwiek z trzech wydań), nie może wątpić ani przez chwilę, że Śniadecki był znakomitym dydaktykiem. Jego język, sposób narracji, jasny, odwołujący się do doświadczeń czytelników opis oraz prostota wyjaśniania chemicznych zawiłości czynią z tego podręcznika lekturę interesującą, przystępną, działającą na wyobraźnię i inspirującą. Jak dalece inspirującą świadczy nazwa „Promieniści”, którą przyjęło zawiązane w Wilnie tajne stowarzyszenie studentów. Wszyscy bez wyjątku założyciele tego stowarzyszenia byli uczniami Śniadeckiego.

W dawnej Bibliotece Wróblewskich w Wilnie (obecnie biblioteka Litewskiej Akademii Nauk) znajduje się liczący 55 stron pokaźnego formatu Żurnal studentów chodzących na chemię w latach 1814-1822 ${ }^{21}$. Na liście studentów z roku akademickiego 1815/1816, pod numerem 107 został zapisany ,słuchacz Mickiewicz Adam - kandydat stanu nauczycielskiego", który na egzaminie u profesora Śniadeckiego uzyskał ocenę dobrą. Na tej samej liście pod numerem 25 widnieje nazwisko Jana Czeczota (1796-1847) oraz pod numerem 191 - Tomasza Zana (1796-1855). Rok później u Śniadeckiego studiował chemię Ignacy Domeyko (1802-1889). Z tamtych to czasów właśnie pochodzi młodzieńczy wiersz Mickiewicza: Cztery toasty pewnego chemika na cześć istot promienistych.

Oprócz pierwiastków promienistych do ciał prostych zaliczano także kwasoród, saletroród (azot), wodoród, węglik (Śniadecki sądził, że węglik w czystej postaci to diament), fosfor i siarkę; poza tym metale (złoto, platyna, srebro, miedź, ołów, żelazo, żywe srebro (rtęć), zynk (cynk), arszenik (arsen), molibden, wolfram albo tungsten, manganez (mangan), antymon, bizmut, kobalt, nikiel, uran, tytan, tellurium (tellur), chromium (chrom); dalej ziemie (krzemionka, wapno, magnezja, baryta, glinka, stroncjana, cyrkona, glucyna [tlenek berylu]) oraz dwa alkalia: potaż i sodę (węglan potasu $\mathrm{K}_{2} \mathrm{CO}_{3}$, węglan sodu $\mathrm{Na}_{2} \mathrm{CO}_{3}$ lub wodorotlenek sodu) $)^{22}$.

${ }^{20}$ Idem, Początki chemii dla użycia stuchaczów przy Imperatorskim Wileńskim Uniwersytecie ułożone przez Jędrzeja Śniadeckiego, wyd. 3 popr. i poprawne, t. 1, Wilno 1816, s. 55-81.

${ }^{21}$ Archiwum Biblioteki Litewskiej Akademii Nauk w Wilnie, rps, sygn. F9-123.

22 J. Śniadecki, Poczatki chemii: stosownie..., t. 1, s. 38-39. 
Śniadecki omówił właściwości fizyczne i chemiczne wszystkich po kolei wymienionych pierwiastków. W pierwszym wydaniu Początków chemii dużo uwagi poświęcił najnowszej wówczas wiedzy o gazowych składnikach wody i powietrza atmosferycznego. Metale charakteryzował pod kątem ich aktywności chemicznej oraz podatności na obróbkę plastyczną, o ziemiach zaś napisał, iż są to istoty suche, niepalne, niepoddające się stapianiu, kruche, rozsypujące się w proch i odporne na działania chemiczne.

Wydanie trzecie podręcznika zawierało o 15 pierwiastków więcej. Były to nowo odkryte: niob, pallad, rod, osm, ind, magnez, wanad, bar, bor, sód, potas, wapń, stront, jod i cer.

Pierwiastek, który w nomenklaturze francuskiej otrzymał nazwę oxygène (z greki oxykwaśny, gennao - rodzę), przetłumaczoną następnie przez Śniadeckiego na kwasoród, odegrał w ówczesnej chemii wyjątkową rolę. Jego nazwa zawierała całą kwintesencję nowej teorii spalania, odsyłającej do lamusa ugruntowaną od niemal stu lat flogistonową doktrynę Georga Stahla (1659-1734).

\section{Kwasowa teoria spalania}

Według nowych poglądów spalanie było procesem łączenia się ciał palnych z kwasorodem, w wyniku czego powstawały kwasy. Sam kwasoród w czystej postaci nie był znany, był natomiast znany roztwór tego pierwiastka w ciepliku, czyli gaz kwasorodny. Podobnie rzecz się miała z innymi ciałami występującymi w postaci gazowej - saletrorodem, i gazem saletrorodnym (nazywanym też azotem), wodorodem i gazem wodorodnym.

„Każde ciało spalone czyli złączone do nasycenia z kwasorodem jest kwasem” ${ }^{23}$ nauczał Śniadecki. Ponieważ rozmaitych substancji palnych znano bardzo dużo, można było się spodziewać równie dużej liczby różniących się między sobą kwasów. Gdy spalano siarkę, powstawał kwas siarkowy. Gdy to samo czyniono z fosforem, otrzymywano kwas fosforowy, z węglem - węglowy itd. Substancje spalane, które wchodziły w skład kwasów, nadając im swoiste cechy, nazywał Śniadecki zasadami kwasowymi. Mogły być one proste lub złożone, pojedyncze lub podwójne, potrójne itd., w zależności od tego, z ilu składały się pierwiastków. Od zasad kwasowych tworzone były nazwy kwasów.

Charakterystyczne właściwości kwasów, na podstawie których wyodrębniano tę grupę związków, były od dawna dobrze znane. Kwasy miały smak kwaśny, zmieniały niebieskie barwniki roślinne na kolor czerwony, łączyły się z wodą oraz łatwo wchodziły w reakcje z alkaliami, niektórymi ziemiami i wapnami metalicznymi, tworząc sole. Okazało się jednak, że te właściwości są udziałem tylko niektórych produktów spalania. Zaistniały problem starano się więc rozwiązać, przyjmując następujące założenia:

a. Mogą ciała palne przyswoić tylko tyle kwasorodu, że nie wykazują jeszcze właściwości kwasów. Nazywa się je wtedy niedokwasami.

b. Mogą być półspalone i zawierać tyle kwasorodu, że są kwaśne, ale nieznacznie i nawet nietrwale. Noszą wtedy nazwę podkwasów, np. podkwas siarczany, podkwas saletrowy, podkwas fosforyczny.

c. Jeśli ciała są doskonale kwasorodem nasycone, czyli są doskonale ukwaszone, to przysługuje im nazwa kwasów.

${ }^{23}$ Ibidem, s. 189. 
d. Gdy ciało palne przyjmie kwasorodu więcej niż potrzeba do całkowitego nasycenia, wówczas staje się przekwaszone i nosi nazwę przekwasu, np. przekwas siarczany, przekwas solny.

W świetle tej teorii ciekawy przypadek stanowiła woda, czyli - zgodnie z wynikami badań lorda Henry’ego Cavendisha (1731-1810), a później także Lavoisiera - związek chemiczny kwasorodu i wodorodu. Ponieważ wody - ze względu na jej właściwości nie dało się zaliczyć do kwasów, należało uznać, że wodoród mimo gwałtownej reakcji $\mathrm{z}$ kwasorodem, nie poddaje się ukwaszeniu.

Niektóre ziemie i wiele niedokwasów łatwo reagowało z kwasami, tworząc mniej lub bardziej trwałe sole, dlatego też Śniadecki nazywał te substancje zasadami solnymi. Ich skład chemiczny (poza amoniakiem) nie był jeszcze ustalony. Zasady solne, podobnie jak alkalia, charakteryzowały się ostrym gryzącym smakiem i nadawały błękitnym barwnikom roślinnym kolor zielony. Cechy te najwyraźniej przejawiały ziemie - magnezja i wapno, co stało się powodem, że uzyskały miano ziem alkalicznych. Nazwa zachowała się do dziś.

Kwasowa teoria spalania w swojej pierwotnej postaci nie przetrwała długo. Kilka jej korekt znalazło się już w trzecim wydaniu Początków chemii. Przede wszystkim Śniadecki wyrzucił cały nieaktualny już traktat o spalaniu oraz podział na ciała palne i spalone. W świetle bowiem nowych badań, głównie Humphry Davy’ego (1778-1829), Louisa Jacques'a Thénarda (1777-1857) i Louisa Josepha Gaya-Lussaca (1778-1850) okazało się, że ziemie są związkami kwasorodu, a dobrze znany kwas solny (nazywany też przekwasem) wcale kwasorodu nie zawiera; zawiera natomiast wodoród. Śniadecki uznał (w odróżnieniu np. od Berzeliusa), że chloryna (chlor) jest pierwiastkiem, któremu przypisał polską nazwę soliród. Przyjął, że zdolność tworzenia kwasów ma nie tylko kwasoród. Soliród, czyli chloryna, oraz jod dają kwasy z wodorodem. Podobnie siarka i tellur. Doszedł więc do wniosku, że obydwa substraty tworzące wodę są istotami kwaszącymi. Woda okazała się prawdziwą rodzicielką kwasów, o czym świadczyło i to, że bezwodniki kwasowe wykazywały typowe dla kwasów właściwości dopiero po połączeniu z wodą.

W tej nowej sytuacji nazwa kwasoród straciła wiele na uzasadnieniu. Ponieważ jednak przyjęła się w naszej nomenklaturze chemicznej, była używana jeszcze w latach 40. XIX wieku. Później zastąpił ją wyraz tlen, zaproponowany przez Jana Oczapowskiego (1800-1871), lekarza, dawnego ucznia Śniadeckiego. Pamiątką po tlenowej teorii kwasów i zasad jest funkcjonujące do dziś pojęcie stopni utlenienia.

\section{Chemia organiczna}

W ciągu lat dzielących pierwsze i trzecie wydanie Początków chemii poglądy Śniadeckiego na substancjalną budowę przyrody ożywionej ewoluowały w kierunku wyraźnego rozgraniczenia chemii organicznej i chemii fizjologicznej. W pierwszym wydaniu poświęcił autor wzajemnym powiązaniom chemii i funkcjonowania organizmów żywych - czyli roślin, zwierząt i człowieka - duży fragment Części II i całą Część III. W wydaniu z 1807 roku natomiast wprowadził dla tomu drugiego tytuł Chemia 
organiczna ${ }^{24}$ i znacznie ograniczył treści dotyczące fizjologii. Trzecie wydanie, zgodnie z awangardą swoich czasów, zostało podzielone na chemię ogólną i chemię organiczną.

Bilans wiedzy o chemicznym składzie naturalnych materiałów pochodzenia organicznego był już wówczas bogaty. Od czasów Lavoisiera było wiadomo, że cała przyroda ożywiona składa się z kilku zaledwie pierwiastków chemicznych, czyli węgla, wodorodu, kwasorodu, azotu, siarki i fosforu. Wcześniej przez całe stulecia alchemicy i jatrochemicy przedestylowali wiele gatunków roślin i przekonali się, że niezależnie od tego, jakie rośliny poddawano destylacji, otrzymywane frakcje były ciągle takie same. Frakcje te następnie, przez analogię do pierwiastków chemicznych, otrzymały miano pierwiastków roślinnych, które Śniadecki zdefiniował jako „,kombinacje roślinne całkiem w roślinach gotowe". Zbieżność wyników destylacji sugerowała, że wszystkie rośliny muszą być zbudowane z podobnych pierwiastków roślinnych. Potwierdzała to także analiza soków, ekstraktów, wywarów i innych próbek. Do pierwiastków roślinnych zaliczano oleje, kamfory, żywice, kleje, gumy, cukier, krochmal, garbniki, gluten, pierwiastek ekstraktowy, pierwiastek gorzki, pierwiastek chinowy, pierwiastek opajający ${ }^{25}$ (wyodrębniony z opium jako sal Derosne) i jeszcze wiele innych tego rodzaju substancji. Oddzielną i ważną z chemicznego punktu widzenia grupę stanowiły kwasy roślinne, wśród których wymienił Śniadecki kwas szczawiowy, klejowy, jabłkowy, cytrynowy, bursztynowy, winny, galasowy, kamforowy, korkowy i melityczny.

Podobnie rzecz się miała z ciałami pochodzenia zwierzęcego; te zbudowane były z „kombinacji” zwierzęcych, takich jak kwasy zwierzęce, części zwierzęce płynne i stałe, oraz kombinacje występujące w niektórych tylko zwierzętach, np. pierwiastek ostry much hiszpańskich, materia farbująca koszenili, pikromel (składnik żółci), mleko rybie (mlecz).

Ponieważ zarówno pierwiastki roślinne, jak i zwierzęce były pod względem chemicznym ciałami złożonymi, Śniadecki wolał nazywać je kombinacjami i czynił to z dużą konsekwencją. Mechanizm powstawania tych kombinacji oraz w ogóle wszystkich substancji występujących w organizmach żywych wyjaśniał działaniem dwóch rodzajów sił: były to powinowactwa (powinowactwo chemiczne i powinowactwo składu) stanowiące nieodłączną właściwość każdej materii oraz siła organizująca, która towarzyszyła życiu jako jego najistotniejszy atrybut. Śniadecki pisał, że gdy życie ustaje, ustaje wraz z nim działanie siły organizującej. Ciała organiczne poddane są wtedy już tylko powinowactwom, a zwłaszcza powinowactwu chemicznemu, skutkiem czego ulegają rozkładowi, czyli według ówczesnego nazewnictwa - fermentacji. W zależności od warunków, w jakich przebiega rozkład, różne mogą być jego etapy i produkty. Ostatecznym wynikiem każdej fermentacji jest powrót do pospolitych związków mineralnych i pierwiastków chemicznych.

${ }^{24}$ J. Śniadecki, Początki chemii dla użycia stuchaczów akademickich ułożone przez ... filozofii i medycyny doktora, chemii w Wileńskim Imperatorskim Uniwersytecie zwyczajnego publicznego profesora, Towarzystwa Przyjaciót Nauk w Warszawie, Medycznego w Wilnie członka. Edycja powtórna powiększona i poprawna, t. 2: Chemia organiczna, Wilno 1807.

${ }_{25}$ Vide o soli Derosna i morfinie: H. Lichocka, Historia pierwiastka narkotycznego, „Analecta. Studia i Materiały z Dziejów Nauki” 2004, nr 1-2, s. 113-121. 
Własne poglądy na współzależności materii ożywionej i nieożywionej przedstawił Śniadecki, pisząc Teorię jestestw organicznych ${ }^{26}$. Pierwsze wydanie tego dzieła w dwóch tomach ukazało się w Warszawie i Wilnie w latach 1804-1811. Obydwa tomy zostały następnie opublikowane w przekładzie na język niemiecki i francuski. Wersja francuskojęzyczna trafiła na rynek księgarski w 1825 roku. Wcześniej, w 1810 roku, ukazał się wydany po niemiecku w Königsbergu tom pierwszy oraz tom trzeci wydrukowany w Norymberdze w 1821 roku. Jeszcze dzisiaj niemieckie wydanie można odnaleźć np. w Bibliotece Uniwersyteckiej w Wiedniu.

Pod wpływem poglądów zawartych w Teorii jestestw organicznych pozostawał i dawał temu wyraz w swoich publikacjach ${ }^{27}$ Johnannes P. Müller (1801-1858), nazywany później ojcem niemieckiej fizjologii. Dzieło Śniadeckiego bez wątpienia musiał znać również Justus Liebig (1803-1873), gdyż uderzająco podobnie interpretował fenomen przyrody ożywionej. Trudno tego nie zauważyć, czytając np. jego Listy o chemii ${ }^{28}$. Liebig pisał:

zjawisko rozkładu poczyna się u jestestw organicznych natychmiast, skoro tylko śmierć przerywa działanie różnych przyczyn, pod wpływem których utworzyły się związki je składające. Utwory organizmów zwierzęcych i roślinnych (...) podlegają kolei przemian, których ostatecznym wypadkiem jest przemiana ich węgla na kwas węglowy, ich wodoru na wodę, ich azotu na amoniak, ich siarki na kwas siarczany ${ }^{29}$.

Liebig w żadnej swojej pracy nie powoływał się na Śniadeckiego, ale w tym względzie nie należał do skrupulatnych.

\section{Zastosowania chemii}

Kolejne wydania Początków chemii modyfikował autor nie tylko ze względu na potrzebę ich aktualizacji, ale także pod kątem zmieniającego się programu nauczania. O ile bowiem na początku pracy dydaktycznej Śniadeckiego wykłady chemii obejmowały dwa lata studiów, o tyle później na naukę chemii przeznaczono już tylko jeden rok akademicki. W Przedmowie do wydania trzeciego pisał Śniadecki o tym z nutą żalu:

Szkoda, że tak obszerna i do tylu kunsztów, wiadomości i potrzeb zastosowana nauka, nie jest przedmiotem dwóch głównych kursów; a przynajmniej że się nie daje kurs technologii chemicz-

26 J. Śniadecki, Teoria jestestw organicznych, t. 1, Warszawa 1804; idem, Teoria Jestestw organicznych, przez ... Kollegskiego konsyliarza, doktora medycyny, profesora chemii w Imperatorskim Wileńskim Uniwersytecie, wielu towarzystw uczonych członka, t. 2, Wilno 1811.

27 J.P. Müller, Bildungsgeschichte der Genitalien, Düsseldorf 1830, cyt. za: M. Sarnecka-Keller, Zasadnicze tezy biologicznego światopoglądu Jędrzeja Śniadeckiego [w:] Rzecz o Jędrzeju Śniadeckim..., s. 78.

${ }_{28}^{28}$ J. Liebig, Listy o chemii: o jej zastosowaniu w przemyśle, fizjologii $i$ w rolnictwie..., przeł. S. Zdzitowiecki, Warszawa 1845; idem, Nowe listy o chemii zastosowanej do przemyshu, fizjologii i rolnictwa przez dra ... profesora chemii w Uniwersytecie w Monachium, etc, przel. L. Natanson, Warszawa 1854; idem, Najnowsze listy chemiczne..., przeł. A. Rose, Poznań 1858.

${ }^{29}$ Idem, Nowe listy o chemii zastosowanej..., list 27, s. 9. 
nej obok chemii ogólnej. Szkoda, że umiejętności dokładne, które we wszystkich zgromadzeniach uczonych są pierwszym celem pieczołowitości, u nas nie przypadły do smaku ${ }^{30}$.

Dlatego też informacje o praktycznych zastosowaniach chemii odnaleźć można przede wszystkim w pierwszym wydaniu podręcznika Śniadeckiego. Informacje te, obok znaczenia dla rozwoju nauk takich jak mineralogia, medycyna czy sztuka probierska, stanowiły rodzaj teoretycznych podstaw dla wielu rzemiosł - garbarstwa, gorzelnictwa, metalurgii, produkcji mydeł i innych środków piorących, bielenia lnu i konopi, wytwarzania cukru, pokostów, papieru itd.

Sporo miejsca poświęcił Śniadecki barwnikom roślinnym, znajdującym zastosowanie w coraz liczniejszych zakładach włókienniczych. Nauczał, że farbowanie jest czynnością chemiczną opartą na zasadach powinowactwa, farby zaś są albo niedokwasami metalicznymi, albo istotami roślinnymi lub zwierzęcymi, przy czym zwierzęcych jest mało, a roślinnych obficie. Wymienił surowce najczęściej stosowane w celu uzyskania podstawowych barwników (czerwonego, niebieskiego, żółtego i czarnego), wykazując świetną znajomość przedmiotu. Były wśród tych surowców barwierskich materiały roślinne i zwierzęce pochodzenia krajowego oraz znacznie droższe - sprowadzane ze stron odległych. Najliczniejsze były te, z których otrzymywano kolor czerwony i żółty; mniej liczne - dające barwnik niebieski. Najtaniej farbowało się tkaniny na kolor czarny.

Ograniczenie wykładów technologii chemicznej w programie kształcenia na Uniwersytecie Wileńskim wynikało zapewne z samego profilu tej uczelni, nastawionej przede wszystkim na uprawianie „,nauk czystych”. „Naukami stosowanymi” natomiast zajmowały się szkoły innych typów.

\section{West versus ruten}

Sprawa pierwszeństwa odkrycia westu vel rutenu wywołała dotychczas już tyle polemik oraz stała się tematem tylu opracowań i komentarzy, że nie ma powodów, aby się nią tu ponownie zajmować. Najpełniejsze, jak dotąd, informacje o tych kontrowersjach znajdą wszyscy zainteresowani w Wilnie chemicznym ${ }^{31}$ Ignacego Siemiona. Śniadecki zajął się analizą rudy platynowej w 1807 roku. Było to zagadnienie bardzo aktualne, ponieważ właśnie wtedy naukowa prasa światowa rozpisywała się o wyizolowaniu z tego minerału czterech nowych pierwiastków: rodu, osmu, palladu i irydu. Badania Śniadeckiego wskazywały na obecność jeszcze jednego pierwiastka, któremu jego hipotetyczny odkrywca nadał nazwę west (łac. vestium).

Informacja o tym nowym metalu została ogłoszona najpierw $\mathrm{w}$ formie referatu na posiedzeniu publicznym Uniwersytetu Wileńskiego. Referat ten został opublikowany ${ }^{32}$.

${ }^{30}$ J. Śniadecki, Początki chemii dla użycia stuchaczów przy..., t. 1, Przedmowa, s. V.

${ }^{31}$ I.Z. Siemion, op. cit., s. 85-89.

32 J. Śniadecki, Rozprawa o nowym metalu w surowej platynie odkrytym przez ... filozofii i medycyny doktora, chemii w Wileńskim Imperatorskim Uniwersytecie zwyczajnego publicznego profesora, Towarzystwa Królewskiego Przyjaciół Nauk w Warszawie, Medycznego w Wilnie członka. Czytana na publicznym posiedzeniu Imperatorskiego Uniwersytetu Wileńskiego dnia 28 czerwca 1808 d. s., Wilno 1808. 
Jednocześnie do Instytutu Narodowego w Paryżu oraz do Petersburskiej Akademii Nauk zostały wysłane zawiadomienia o dokonanym odkryciu wraz z krótkim opisem przeprowadzonej analizy. Niezależnie od tego Śniadecki powiadomił o swoich wynikach prywatnie Aleksandra Chodkiewicza.

Obie akademie - zgodnie z przyjętymi zwyczajami - zamieściły anons o nowym pierwiastku w swoich organach prasowych. W akademii paryskiej sprawą zajęli się chemicy: Guyton de Morveau, Berthollet i Fourcroy, którzy nie potwierdzili obecności westu w surowej platynie, co stało się początkiem późniejszych, wieloletnich i nierozstrzygniętych do dziś dywagacji. Za odkrywcę piątego platynowca, nazwanego rutenem, uznano w 1844 roku Karla Clausa (1796-1864) - chemika, botanika i farmaceutę, profesora uniwersytetów w Kazaniu i Dorpacie.

$* * *$

Za podsumowanie całości tego artykułu niechaj posłuży znana i chętnie powtarzana anegdota o rozmowie Śniadeckiego z cesarzem Napoleonem Bonaparte latem 1812 roku w Wilnie. Cesarz, informowany o miejscowym uniwersytecie, zapytał nie bez ironii:

- A jakiejże wy tu chemii uczycie?

- Takiej samej jak w Paryżu - odpowiedział bez wahania Śniadecki.

I było to zgodne z prawdą!

\section{Bibliografia}

Archiwum Biblioteki Litewskiej Akademii Nauk w Wilnie, rps, sygn. F9-123.

Bednarczyk A., Jędrzeja Śniadeckiego „, Teoria jestestw organicznych” (1804) w dwusetna rocznice ogłoszenia dzieła, Warszawa 2004.

Dąbkowska M., Początki chemii Jędrzeja Śniadeckiego na tle powstawania polskiej nomenklatury chemicznej [w:] Księga pamiątkowa dziesięciolecia Uniwersytetu Marii Curie-Skłodowskiej w Lublinie 1944-1954, Lublin 1956, s. 177-195.

Fourcroy A.F. de, Filozofia chemiczna czyli fundamentalne prawdy teraźniejszej chemii przez Antoine Francois de Fourcroya. Z francuskiego przełożona przez X. Jana Bystrzyckiego S.P. Towarzystwa Król. Warsz. Przyjaciół Nauk członka, profesora fizyki w szkołach warszawskich, Warszawa 1808.

Guyton de Morveau L.B., Lavoisier A.L., Berthollet C.L., Fourcroy A.F., Méthode de nomenclature chimique on y a joint un nouveau Systême de Caractères Chimiques, adaptés à cette Nomenclature, par MM. Hassenfratz \& Adet, Paris 1787.

Harabaszewski J., Jędrzej Śniadecki, nauczyciel chemii i pisarz rzeczy chemicznych, Lwów 1938.

Hubicki W., Studia chemiczne Jędrzeja Śniadeckiego [w:] Rzecz o Jędrzeju Śniadeckim, red. I. Stasiewicz, Warszawa 1970.

Konopka S., Spis rozpraw i artykułów o Jędrzeju Śniadeckim ogłoszonych w latach od 1840 do 1968 włącznie, „Archiwum Historii Medycyny” 1969, t. 32, z. 1, s. 75-83.

Koskowski B., [Słowo wstępne], Inwentarz Zakładu Chemii dawnego Uniwersytetu Wileńskiego zapoczatkowany przez Jędrzeja Śniadeckiego w roku 1797 i doprowadzony do końca przez Ignacego Fonberga. Materiat archiwalny zebrat i do druku opracowat Kazimierz Stawiński. $W$ hołdzie Jędrzejowi Śniadeckiemu w stuletnia rocznice jego śmierci dokument ten wydaje Polskie Powszechne Towarzystwo Farmaceutyczne, Wilno 1938, s. 9-10. 
Kramsztyk Z., Jędrzej Śniadecki, „Teoryja (!) jestestw organicznych” w obec (!) dzisiejszych pojęć o życiu. Z portretem Śniadeckiego, Warszawa 1874.

Lampe W., Początki chemii Jędrzeja Śniadeckiego, „Roczniki Chemii” 1950, t. 24, nr 1-6, s. 3-10.

Lichocka H., Historia pierwiastka narkotycznego, „Analecta. Studia i Materiały z Dziejów Nauki" 2004, nr 1-2, s. 113-121.

Liebig J., Listy o chemii: o jej zastosowaniu w przemyśle, fizjologii i w rolnictwie przez... przeł. S. Zdzitowiecki, Warszawa 1845.

Liebig J., Najnowsze listy chemiczne..., przeł. A. Rose, Poznań 1858.

Liebig J., Nowe listy o chemii zastosowanej do przemystu, fizjologii i rolnictwa przez dra ... profesora chemii w Uniwersytecie w Monachium, etc, przeł. L. Natanson, Warszawa 1854.

Łagowski S., Jędrzej Śniadecki i jego „, Teoria jestestw organicznych” w setna rocznicę pierwszego jej wydania. Szkic źródtowy i krytyczny, Lwów 1904.

Mierzecki R., Rozwój polskiej terminologii chemicznej, Wrocław 1988.

Müller J.P., Bildungsgeschichte der Genitalien, Düsseldorf 1830.

Rzecz o Jędrzeju Śniadeckim, red. I. Stasiewicz, Biblioteka Wiedzy Współczesnej - Omega, t. 165, Warszawa 1970.

Sarnecka-Keller M., Zasadnicze tezy biologicznego światopogląu Jędrzeja Śniadeckiego [w:] Rzecz o Jędrzeju Śniadeckim, red. I. Stasiewicz, Warszawa 1970, s. 62-79.

Sarnecki K., Śniadecki - analityk, ale czy odkrywca rutenu? [w:] Rzecz o Jędrzeju Śniadeckim, red. I. Stasiewicz, Warszawa 1970, s. 52-61.

Siemion I.Z., Wilno chemiczne do połowy XIX stulecia, Komitet Historii Nauki i Techniki PAN. Rozprawy z Dziejów Nauki i Techniki, t. 20, Warszawa 2009.

Śniadecki J., Objaśnienie niektórych punktów w nauce o ciepliku. Rzecz na posiedzeniu akademickim Uniwersytetu Wileńskiego dnia 15 marca 1815 roku czytana [w:] J. Śniadecki, Dzieła, t. 3, Warszawa 1840.

Śniadecki J., Początki chemii dla użycia stuchaczów akademickich ułożone przez ... filozofii i medycyny doktora, chemii w Wileńskim Imperatorskim Uniwersytecie zwyczajnego publicznego profesora, Towarzystwa Przyjaciól Nauk w Warszawie, Medycznego w Wilnie członka. Edycja powtórna powiększona i poprawna, t. 2: Chemia organiczna, Wilno 1807.

Śniadecki J., Początki chemii dla użycia stuchaczów przy Imperatorskim Wileńskim Uniwersytecie ułożone przez Jędrzeja Śniadeckiego. Wydanie trzecie poprawione i poprawne, t. 1, Wilno 1816.

Śniadecki J., Początki chemii: stosownie do teraźniejszego tey umiejętności stanu dla pożytku uczniów i stuchaczów ułożony y za wzór lekcyi akademickich służyć mające, Wilno 1800.

Śniadecki J., Rozprawa o nowym metalu w surowej platynie odkrytym przez ... filozofii $i$ medycyny doktora, chemii w Wileński Imperatorskim Uniwersytecie zwyczajnego publicznego profesora, Towarzystwa Królewskiego Przyjaciót Nauk w Warszawie, Medycznego w Wilnie członka. Czytana na publicznym posiedzeniu Imperatorskiego Uniwersytetu Wileńskiego dnia 28 czerwca 1808 d. s., Wilno 1808.

Śniadecki J., Teoria jestestw organicznych medycyny doktora... t. 1, Warszawa 1804.

Śniadecki J., Teoria Jestestw organicznych, przez... Kollegskiego konsyliarza, doktora medycyny, profesora chemii w Imperatorskim Wileńskim Uniwersytecie, wielu towarzystw uczonych członka, t. 2, Wilno 1811.

Wrzosek A., Jędrzej Śniadecki, Przedmowa do „Krótkiego rysu chemii dla użytku szkót narodowych W. Księstwa Warszawskiego”. Z rękopisu wydat i wstępem poprzedził..., „Wszechświat” 1903, t. 22, nr 11 (1084), s. 161-164.

Żurawska E., Konieczyńska J., Jędrzej Śniadecki 1768-1838. Bibliografia w wyborze, Żnin 1970. 